\title{
手術室に打ける蓄尿バッグの適正管理に対する介入の効果検討
}

\author{
松下 真奈 1 - $\cdot$ 木村 美緒 $\left.{ }^{1}\right) \cdot$ 橋本 明子2,3) $\cdot$ 井川 順子 2 \\ 山中 寛恵 ${ }^{2)} \cdot$ 長尾 美紀 $^{3)} \cdot$ 高倉 $\quad$ 俊二 ${ }^{3)} \cdot$ 一山 智3)
}

\section{Effect of Appropriate Management of the Urine Collection Bag in the Operation Room}

\author{
Mana Matsushita ${ }^{1)}$, Mio KimUra ${ }^{1)}$, Akiko Hashimoto ${ }^{2,3)}$, Junko IgawA ${ }^{2)}$, \\ Hiroe YamanaKa ${ }^{2)}$, Miki NaGaO ${ }^{3)}$, Syunji TAKAKURA ${ }^{3)}$ and Satoshi ICHIYAmA ${ }^{3)}$ \\ ${ }^{1)}$ Surgery Unit, ${ }^{2)}$ Nursing Department, and \\ 3) Department of Infection Control and Prevention, Kyoto University Hospital
}

(2014 年 10 月 6 日 受付 $\cdot 2015$ 年 3 月 18 日 受理)

\begin{abstract}
要旨
カテーテル関連尿路感染症 (catheter-associated urinary tract infection: CAUTI) は院内感染の約 40\%を占め, その約 $80 \%$ が尿道留置カテーテルと蓄尿バッグの操作抢よび留置後に発生している と考えられている. しかし, A 大学病院手術室に抢ける調査の結果, 床への接触等による蓄尿バ ッグの污染が懸念された. CAUTI 予防のための蓄尿バッグの適正使用と污染防止を目的として, 蓄尿バッグ専用ホルダー(以下，ホルダー）と尿排液専用バケッ(以下，バケッ)の設置を行ったが, それらの使用率や手術室看護師の CAUTI 予防に関する意識が低い事が分かった．そこで本研究で は, 手術室看護師を対象にした学習会により, ホルダーとバケツの使用率および適正使用率の向上 を図り, 質問紙調査と術中ラウンド調査からその効果を評価した. 介入前後で, ホルダーの使用率 が 35.9\%から 81.8\%に上昇した。 また，バケツの使用率は高く維持され，ホルダーの使用時は排 液口のはずれ抢よび接触件数が減少した．質問紙調査や術中ラウンド調査に括いて使用法や注意 点, ホルダーの効果を具体的に示す事で, 対象者への意識づけが得られたと考えられた. またホル ダーは蓄尿バッグをより安定して保持できる特徴を持ち, 排液口の活染を予防できると考えられ た．質問紙調査や術中ラウンド調査による介入は, CAUTI 防止を目的としたホルダー拉よびバケ ツの使用徹底のために効果的であった.
\end{abstract}

Key words : カテーテル関連尿路感染症, 手術室, 尿道留置カテーテル, 蓄尿バッグ

序文

米国での調査によると, カテーテル関連尿路感染症 (catheter-associated urinary tract infection: CAUTI)は 院内感染の約 $40 \%$ を占め, その約 $80 \%$ が尿道留置力 テーテルと蓄尿バッグの操作および留置後に発生してい ると考えられている1,2). 微生物の進入経路にはカテー テルの外側経路と内側経路がある. 手術室では麻醉管理 上，尿道カテーテルの挿入例が多く，手術中における CAUTI の主な外側経路としては排液口が，内側経路と

京都大学医学部附属病院 ${ }^{1)}$ 看護部手術部, 2) 看護部, 3 )感染制 御部
しては挿入時や会陰・直腸に定着している菌が尿道口よ り侵入することが主と考えられる32.

$\mathrm{A}$ 大学病院に拈いて, 尿道留置カテーテルは, 閉鎖 式ドレナージシステムが基本であるが，挿入後の手術操 作中は, 術式によっては体位変換時に患者の安全管理に 意識が集中してしまうなど, 尿道留置カテーテルおよび 蓄尿バッグの清潔保持に関して配慮できていない状況が 見受けられた．特に，蓄尿バッグが直接床に置かれてい ることによる污染，尿排液時に排液バケツを他の用途と 兼用していたため, 跳ね返りによる排液口の污染が懸念 された．さらに，蓄尿バッグが手術用ベッドのレールに かけられ，手術時体位ローテーション実施時に，蓄尿バ 
ッグが膀胱よりも高位となる事による, 尿の逆流が懸念 された．そのため, 蓄尿バッグの污染防止を目的に, 蓄 尿バッグ専用ホルダー(以下, ホルダー) と, 尿排液専用 バケッ(以下，バケッ)の設置を行った.

ホルダーは, 一定の高さでかつ安定して蓄尿バッグを かけることが可能であり，手術中の体位ローテーション 時の尿逆流防止にも効果が期待できる. またバケツを設 置することで, 従来の多用途の排液バケツと比較し, 尿 排液時の蓄尿バッグ排液口の污染予防が期待できる.

しかし現状調査の結果, 専用ホルダーの使用率が低い 事が分かった．またホルダーおよびバケツを使用してい ても, 適正使用方法が徹底されていない例が見られる 事, 手術室看護師のCAUTI 予防に関する意識が低い事 が分かった。

今回, ホルダーおよびバケッの使用率抢よび適正使用 率を上昇させ, 蓄尿バックの污染防止と適正管理を徹底 する事を目的に, 手術室看護師を対象に学習会・質問紙 調査・術中ラウンド調查を実施し効果検討を行ったので 報告する.

\section{材料と方法}

\section{1. 調査期間}

全調查期間は 2012 年 9 月 2013 年 9 月. 全調查期 間中のうち, 2012 年 9 月にバケッ, 2013 年 2 月にホル ダーを設置した。また， 2013 年 6 月〜 7 月に学習会前 現状調査(術中ラウンド調査打よび質問紙調査), 2013 年 8 月上旬に学習会, 2013 年 8 月中旬 9 月に学習会 後調査(術中ラウンド調查抢よび質問紙調查)を実施した。

\section{2. 対象}

対象者は, 手術室勤務の全看護師 65 名とした. 学習 会前現状調查 (以下, 学習会前) と学習会後現状調查 (以 下, 学習会後)の対象者は, 各々の期間に手術室に勤務 していた全看護師のうち, 間接介助を担当していた看護 師とした．学習会後に間接介助を担当するようになった 場合は, 学習会後の対象者に加えた. また学習会前の対 象者になっていたが, 学習会後に手術室勤務でなくなっ た場合は，学習会後の対象者からはずした，そのため, 学習会前と学習会後で 10 名の職員が入れ変わった.

\section{3. ホルダーおよびバケツ(図 1)の設置}

設置時に適正使用方法拧よび適正排液方法を，文書と 部署内電子メール，朝のカンファレンスで各々 1 回の 周知を行った。適正使用方法とは，ホルダーに蓄尿バッ グが床面に接することなくかけられている6 ${ }^{6}$ ，蓄尿バッ グが傾いていないこととした。また，適正排液方法と は，尿排液時にバケッに排液口が接していない，未使用 のバケッを使用することとした ${ }^{4)}$.

\section{4. 学習会}

CAUTI に関する学習会を実施し，適正使用の目的と

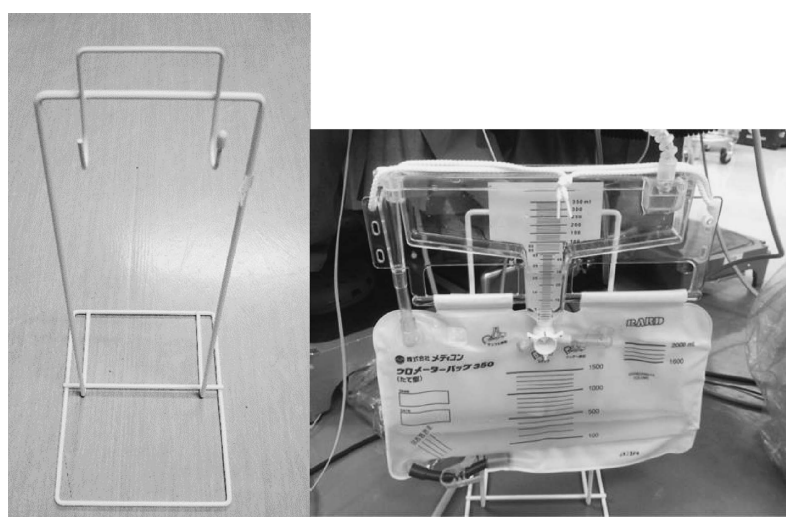

図 1 蓄尿バッグ専用ホルダー

写真右のように蓄尿バッグをフック部にかけて使用している.

表 1 質問紙調查表と正答率(質問 1～3)

\begin{tabular}{|c|c|c|c|c|}
\hline $\begin{array}{l}\text { 質闑 } \\
\end{array}$ & 質問内容/選択肢 & $\begin{array}{l}\text { 回答番号 } \\
\text { と選択肢 }\end{array}$ & $\begin{array}{c}\text { 学習会前 } \\
\text { (前) \% } \\
N=38\end{array}$ & $\begin{array}{c}\text { 学習会後 } \\
\text { (介後) \% } \\
N=42\end{array}$ \\
\hline 1 & $\begin{array}{l}\text { 尿路感染は院内 } \\
\text { 染の } 0 \% \text { 占 } \\
\text { 女る }\end{array}$ & $\begin{array}{l}\text { (1) } 10 \\
\text { (2) } 20 \\
\text { (3) } 30 \\
\text { (4) } 40 \\
\text { (5) } 50\end{array}$ & 46.2 & 61.9 \\
\hline 2 & $\begin{array}{l}\text { 尿路感染のうち } \\
\text { CAUTI は } 0 \% \text { を } \\
\text { 占める }\end{array}$ & 自由回答 & 46.2 & 38.1 \\
\hline 3 & 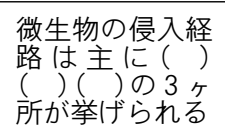 & 自由回答 & $28.2^{*}$ & $59.5^{*}$ \\
\hline
\end{tabular}

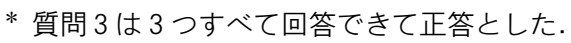

方法を再度周知した．学習会内容は現状調查結果に沿っ て実施しホルダーの使用率が低い事，適正に使用しない と蓄尿バッグが傾き，排液口が污染されやすいことを説 明した。

また，質問紙調査結果より，CAUTI に関する項(表 1)への正答率が低かったため, CAUTI の発生状沉, 感 染経路について説明した．学習会は日勤勤務終了後の時 間外に, 同じ内容で 2 回実施し, ぞちらか 1 回の参加 を促した。

参加率は $50 \%$, 参加者の平均手術室経験年数は 2 年 8 か月, 不参加者は 7 年 9 か月であり，不参加者へのフ オローは実施していない。

\section{5. 効果判定}

学習会前と学習会後に効果判定のための質問紙調查 （表 1，表 2) と術中ラウンド調査(表 3)を実施した。術 中ラウンド調査は各々 1 週間, 時間外延長手術を対象 に実施した。質問紙抢よび術中ラウンド調査内容は，学 習会前と学習会後で同様の内容とした，学習会後の質問 
表 2 質問紙調査表と回答率(質問 4～13)

\begin{tabular}{|c|c|c|c|c|c|}
\hline $\begin{array}{l}\text { 質問 } \\
\text { 番号 }\end{array}$ & 質問内容/選択肢 & 回答番号と選択肢 & $\begin{array}{l}\text { 学習会前 } \\
\text { (介入前) \% } \\
N=38\end{array}$ & $\begin{array}{l}\text { 学習会後 } \\
\text { (介入後) \% } \\
N=42\end{array}$ & $\begin{array}{c}\mathrm{p} \text { 值 } \\
\text { Mann-Whitney } \\
\cup \text { test }\end{array}$ \\
\hline \multirow{3}{*}{4} & \multirow{3}{*}{ 蓄尿バッグ専用ホルダーについて } & (1) 知っている & 87.2 & 95.2 & \multirow{3}{*}{0.193} \\
\hline & & (2) 何亡なく知っている & 10.3 & 4.8 & \\
\hline & & (3) 知らない & 2.6 & 0 & \\
\hline \multirow{4}{*}{5} & \multirow{4}{*}{$\begin{array}{l}\text { 蓄尿バッグ専用ホルダーを使用して } \\
\text { いる }\end{array}$} & (1) 常に使用している & 35.9 & 66.7 & \multirow{4}{*}{0.003} \\
\hline & & (2) 時々使用している & 64.1 & 28.6 & \\
\hline & & (3) 使用していない & 0 & 0 & \\
\hline & & (4) 無回答 & 0 & 4.8 & \\
\hline \multirow{3}{*}{6} & \multirow{3}{*}{$\begin{array}{l}\text { 蓄尿バッグの排液ロが床やべッドな } \\
\text { どに接触してはいけないことについ } \\
\text { て }\end{array}$} & (1) 知っている & 97.4 & 100 & \multirow{3}{*}{0.297} \\
\hline & & (2) 何となく知っている & 2.6 & 0 & \\
\hline & & (3) 知らない & 0 & 0 & \\
\hline \multirow{3}{*}{7} & \multirow{3}{*}{$\begin{array}{l}\text { 6. について，接触しないよう注意 } \\
\text { している }\end{array}$} & (1) 常にしている & 94.9 & 95.2 & \multirow{3}{*}{0.940} \\
\hline & & (2) 時々している & 5.1 & 4.8 & \\
\hline & & (3) していない & 0 & 0 & \\
\hline \multirow{3}{*}{8} & \multirow{3}{*}{$\begin{array}{l}\text { 蓄尿バッグの排液ロがはずれていな } \\
\text { いか注意している }\end{array}$} & (1) 常にしている & 82.1 & 85.7 & \multirow{3}{*}{0.662} \\
\hline & & (2) 時々している & 15.4 & 11.9 & \\
\hline & & (3) していない & 2.6 & 2.4 & \\
\hline \multirow{3}{*}{9} & \multirow{3}{*}{$\begin{array}{l}\text { 蓄尿バッグを蓄尿バッグ専用ホル } \\
\text { ダー外にかけている }\end{array}$} & (1) 常にしている & 5.1 & 4.8 & \multirow{3}{*}{0.004} \\
\hline & & (2) 時々している & 92.3 & 64.3 & \\
\hline & & (3) していない & 2.6 & 31.0 & \\
\hline \multirow{4}{*}{10} & \multirow{4}{*}{$\begin{array}{l}\text { 尿を排液する際, 尿排液専用バケツ } \\
\text { を使用している }\end{array}$} & (1) 常に使用している & 94.9 & 90.5 & \multirow{4}{*}{0.315} \\
\hline & & (2) 時々使用している & 2.6 & 0 & \\
\hline & & (3) 使用していない & 0 & 0 & \\
\hline & & (4) 無回答 & 2.6 & 9.5 & \\
\hline \multirow{4}{*}{11} & \multirow{4}{*}{$\begin{array}{l}\text { 尿を排液する際, 液口が排液容器に } \\
\text { 接触してはいけないことを知ってい } \\
\text { る }\end{array}$} & (1) 知っている & 94.9 & 83 & \multirow{4}{*}{0.307} \\
\hline & & (2) 何となく知っている & 2.6 & 7 & \\
\hline & & (3) 知らない & 0 & 0 & \\
\hline & & (4) 無回答 & 2.6 & 10 & \\
\hline \multirow{4}{*}{12} & \multirow{4}{*}{$\begin{array}{l}11 \text { にしいて，接触しないように注意 } \\
\text { している }\end{array}$} & (1) 常にしている & 94.9 & 83.3 & \\
\hline & & (2) 時々している & 2.6 & 7.1 & \\
\hline & & (3) していない & 0 & 0 & $30 /$ \\
\hline & & (4) 無回答 & 2.6 & 9.5 & \\
\hline & & 選択数 (延べ数)介入前 69 個， & 介入後 50 佔 & & \\
\hline & & (1) かける場所がない & 13 & 10 & \\
\hline & & $\begin{array}{l}\text { (2) 蓄尿バッグ専用ホルダーが近くにな } \\
\text { い }\end{array}$ & 15.9 & 8 & \\
\hline & & (3) 安定性が高い & 10.1 & 6 & \\
\hline & & (4) 麻酔科がかけた & 8.7 & 6 & \\
\hline 13 & $\begin{array}{l}9 \text { で(1)か(2)を回答した方は理由を選 } \\
\text { 択 }\end{array}$ & $\begin{array}{l}\text { (5) 蓄尿バッグ専用ホルダーを使うまで } \\
\text { の時的にかける }\end{array}$ & 20.3 & 34 & \\
\hline & $\begin{array}{l}* \text { 回答数は選択数の総数に対する\% } \\
\text { で示す }\end{array}$ & $\begin{array}{l}\text { (6) 蓄尿バッグ専用ホルダーを置くス } \\
\text { ペースがない }\end{array}$ & 18.8 & 16 & \\
\hline & & $\begin{array}{l}\text { (7) 蓄厡バッグ専用ホルダーを使用しな } \\
\text { くて適正にバッグを管理できる }\end{array}$ & 13 & 14 & \\
\hline & & (8) その他(自由記載) & 0 & $\begin{array}{l} \\
\text { ・距離が届力 } \\
\text { ・頭低位なと } \\
\text { ダーが設置 } \\
\text { ・記載なし( }\end{array}$ & $\begin{array}{l}6 \\
\text { ない(2) } \\
\text { で専用ホル } \\
\text { できない(2) } \\
\text { ) }\end{array}$ \\
\hline
\end{tabular}


表 3 術中ラウンド調査表と学習会前後の結果

\begin{tabular}{|c|c|c|c|c|c|}
\hline $\begin{array}{l}\text { 調查 } \\
\text { 番号 }\end{array}$ & 調査項目/評価 & & $\begin{array}{c}\text { 学習会前 } \\
N=39\end{array}$ & $\begin{array}{c}\text { 学習会後 } \\
N=44 \\
N=44\end{array}$ & $\begin{array}{c}p \text { 值 } \\
\text { Mann-Whitney } \\
\cup \text { test }\end{array}$ \\
\hline 1 & ホルダーを使用している & 常に使用している & 35.9 & 81.8 & 0.002 \\
\hline 2 & $\begin{array}{l}\text { ホルダーが適正に使用できている } \\
\text { ・斜めになっていない } \\
\text { ・バッグが床に接触していない }\end{array}$ & 適正に使用できている & 92.9 & 94.4 & 0.589 \\
\hline 3 & バッグをベッドレールにかけている & かけている & 53.8 & 18.2 & 0.023 \\
\hline 4 & $\begin{array}{l}\text { バッグをホルダー・ベッドレール以外にかけている } \\
\text { (場所記載) }\end{array}$ & かけている & 10.3 & 0 & 0.001 \\
\hline 5 & 排液ロがキャップからはずれていない & はずれている & 5.1 & 4.6 & 0.871 \\
\hline 6 & 排液ロが床やベッド等に接触していない & 接触している & 28.2 & 11.4 & 0.195 \\
\hline
\end{tabular}

紙に，学習会の参加の有無を問う質問を追加した．学習 会前と学習会後の質問紙および術中ラウンド調査, 学習 会の参加者と不参加者の比較検討を実施した. 各々の全 体数に対する\%で示し，さらに小数点第二位を四捨五入 した。統計解析は，Mann-Whitney 検定を用いた。ま た，専用ホルダ一使用時と非使用時の，排液口のはず れ・接触件数の比較検討を行い, 統計解析は Fisher の 正確確率検定を用いた。 各々の検定で $\mathrm{p}$ 值は 0.05 未満 で有意差ありとした。

\section{6. 倫理的配慮}

本研究は, 当院医の倫理委員会 $(\mathrm{E}-1845)$, 看護部倫 理委員会 (13-007)の承認を受けて実施した。本研究の 意義や内容実施主体等についての詳細は，手術室勤務の 全看護師に対し文書(質問紙に添付)と口頭で説明した。 参加に同意が得られた場合は, 質問紙回答を持って同意 を得た. また, 研究協力が得られた場合にも, 同意撤 回・途中離脱が可能であること，それによる不利益がな いことを説明した。

\section{結 果}

質問紙回答者の平均手術室経験年数は学習会前 7 年 1 か月，学習会後 5 年 2 か月であった.

\section{1. 質問紙調査比較}

質問紙回収率は，学習会前 $72.2 \%(\mathrm{~N}=38)$, 学習会 後 $77.8 \%(\mathrm{~N}=42)$ であった。質問紙調査結果より，尿 排液専用バケツの適正使用に関する質問 (表 2)への回答 では，「使用している」が学習会前 $94.9 \%$ ，学習会後 90.5\%と，共に高く維持されていた．また，バケツの適 正排液率は学習会前後で高く維持されていた．ホルダー の使用に関する質問では，「常に使用している」との回 答が，学習会前 $35.9 \%$ に対し学習会後は $66.7 \%$ と上昇 した $(\mathrm{p}=0.003)$. ホルダーを使用しない理由として最も 多かったものは，学習会前は「麻酔科がベッドのレール にかけるから」，「ホルダーが近くにない」等の項目への

\begin{tabular}{|c|c|c|c|}
\hline & \multicolumn{2}{|c|}{ はずれ・接触(件) } & \multirow{2}{*}{$\begin{array}{c}\mathrm{p} \text { 值 } \\
\text { Fisher's exact } \\
\text { test }\end{array}$} \\
\hline & あり & なし & \\
\hline \multicolumn{4}{|l|}{ 介入前 $N=39$} \\
\hline ホルダー使用 & 1 & 13 & 0.013 \\
\hline ホルダー非使用 & 12 & 13 & \\
\hline \multicolumn{4}{|l|}{ 介入後 $N=44$} \\
\hline ホルダー使用 & 2 & 34 & 0.001 \\
\hline ホルダー非使用 & 5 & 3 & \\
\hline
\end{tabular}

回答が多く，学習会後では，「ホルダーまで届かない」, 「頭低位手術などで，ホルダーが設置できない」などや むを得ず使用していない，といった自由回答が介入前の 0 件に対し，学習会後は 6 件となった.

\section{2. 術中ラウンド調査比較}

調査件数は, 学習会前 39 件, 学習会後 44 件であっ た。体位別にみると，学習会前は，仰臥位 18 件，側臥 位 7 件, 砕石位 6 件, 腹臥位 7 件であり，学習会後 は, 仰臥位 29 件, 側臥位 5 件, 砕石位 9 件, 腹臥位 1 件であった。学習会前後で比較した結果 (表 3), ホル ダーの使用率は学習会前 $35.9 \%$ から学習会後 $81.1 \%$ に 上昇した $(\mathrm{p}=0.002)$ 。また，ホルダーの適正使用率は， 学習会前 $92.9 \%$ から学習会後 $94.4 \%$ と学習会前後共に 高い率を示した．蓄尿バッグをベッドレールにかけてい る割合は， $53.8 \%$ から 18.2\% と減少した $(\mathrm{p}=0.023)$. 「蓄尿バッグ専用ホルダー・ベッドレール以外にかけて いる」の内訳は，学習会前は「離被架の固定具にかけて いる」 1 件，「床に直接置いている」3 件，学習会後は 0 件と減少した $(\mathrm{p}=0.001)$ ．ホルダー使用時の方がそれ以 外を使用した場合と比較したところ，学習会前 $(\mathrm{p}=$ $0.013)$ と学習会後 $(\mathrm{p}=0.001)$ のそれぞれの時期におい て，排液口のはずれ及び接触件数が少なかった（表 4). 


\section{3. 学習会}

学習会参加者と不参加者で, 質問紙調査結果を比較し たところ, すべての項目で $\mathrm{p}$ 值は 0.05 以上となり, 有 意差は認められなかった。

\section{考察}

バケツの使用率は設置後約 10 か月を経過し，当初の 使用目的と，排液口をバケツに接触させないなどの適正 排液方法の呼びかけの周知により，学習会前後で使用率 は高く維持されていたと考えられる.

ホルダーに関しては，使用目的や効果が十分に周知さ れておらず，ホルダーの設置後から学習会までの 4 か 月間，使用率が低くなっていたと推測された．学習会に おいて使用方法や注意点, ホルダーを使用することで蓄 尿バッグがより清潔に保持されるといった効果を具体的 に示した事, 学習会後のラウンドの開始時にホルダーの 使用を促した事，さらに質問紙調査を実施したことで， 対象者への意識づけが得られ，ホルダーの使用率が上昇 したと考えられた.

回答内容より，学習会前には麻酔科医に管理を任せて いる, 手術ベッドのレールに掛ける方が，より安定性が 高いなどの認識があったが，学習会後は看護師が主体的 にホルダー使用を試みている様子が伺えた．ホルダーの 使用目的やその効果を具体的に示すことで，それらの有 用性が対象者に理解され，できるだけホルダーを使用す る，という意識づけが得られたと考えられた。

学習会参加者の手術室経験年数が平均 2 年 8 か月と 浅く, 基本的手術業務 (清潔器械の扱い, 患者の体位保 持時や生体モニター観察による危険予測など)の習熟や 手術野の感染管理に意識が集中しやすいこと, また, 経 験の長いスタッフの学習会参加率が低かったため, 学習 会による介入効果については今後の課題である.

今回の研究に抢洨果には, 学習会以外にも質問紙 内容の CAUTI やホルダーおよびバケツの使用方法に関 する項目, 朝のカンファレンスでの呼びかけが影響した 可能性が高い，学習会は日勤後の勤務時間外に実施する ことが多く, 経験年数の長いスタッフ程日勤勤務が少な く参加者が少なくなったと考えられた. さらに経験年数 が多いスタッフは，リーダー業務や委員会業務を抱えて おり，それらの忙しさから学習会参加に対して腰が重く なっていることも原因と考えられる．学習会の実施場所 や時間の設定，呼びかけ方法について検討が必要である と考える.

カテーテル関連尿路感染症予防のための CDC ガイド ラインによると,「採尿バッグは膀胱よりも常に低い位 置を保つ，バッグは床に置かない」とある5).

ホルダーとバケツの使用により, 蓄尿バッグが安易に 污染されることを防ぐことは明らかとなった。しかし，
これらの使用とCAUTI 防止との関連性は証明されてい ない、また，本研究では学習会による介入を実施しなか った場合の対象が設定できておらず，介入しないと CAUTI 予防のための知識向上やホルダーとバケツの使 用状況が改善しないことは示せないため, これらは本研 究の限界であると考える。

\section{結 論}

質問紙調査や術中ラウンド調査による介入は, CAUTI 防止のための蓄尿バッグ取り扱いに関する意識抢よ び知識向上につながり，ホルダーの使用率上昇につなが った。 またホルダーとバケツの使用徹底を図ることがで きた．ホルダーの使用は，排液口のはずれ・接触防止の ために効果的であった.

バケツの使用率は使用方法と目的が十分周知されてお り, 高い率を維持していた. 学習会の参加者に経験年数 の偏りが生じたため, 今回の学習会による効果への影響 は少なかった事が予想され，開催方法や呼びかけ方法に ついて検討が必要である. 今後もさらなる意識向上と管 理徹底のため, 定期的なラウンド調査やスタッフへの呼 びかけを行うなど啓蒙活動を継続していく必要がある. さらには，導尿時の手指衛生手順抢よび挿入手技の統一 化を目指していくことも重要であると考える.

\section{利益相反について : 利益相反はない}

\section{文献}

1) Saint S, Wiese J, Amory JK, Bernstein ML, Patel UD, Zemencuk JK, et al: : Are physicians aware of which of their patients have indwelling urinary catheters? Am J Med 2000; 109: 476-80.

2) Hooton TM, Bradley SF, Cardenas DD, Colgan R, Geerlings SE, Rice JC, et al.; Infectious Diseases Society of America: Diagnosis, prevention, and treatment of catheter-associated urinary tract infection in adults: 2009 International Clinical Practice Guidelines from the Infectious Diseases Society of America. Clin Infect Dis 2010; 50: 625-63.

3）沼口史衣 : 尿道カテーテル関連感染とその管理. 感染管 理ナーシング(Nursing Mook 9). 学習研究社, 東京, 2002, p. 129-34.

4）中川みゆき：尿路カテーテル留置に伴う尿路感染症の サーベイランスと看護. 看技 2003; 49(7): 595-600.

5）矢野邦夫 (監訳) : カテーテル関連尿路感染の予防のため の CDC ガイドライン 2009. http://www.medicon.co. $\mathrm{jp} / \mathrm{views} / \mathrm{pdf} / \mathrm{CDC} \_g u i d e l i n e 2009 . p d f: 2013$ 年 8 月 15 日現在

6）松本哲郎：尿路感染対策からみた膀胱留置カテーテルの 管理. 看護技術 2003; 49(7): 590-4.

〔連絡先：=606-8507 京都市左京区聖護院川原町 45 京都大学医学部附属病院看護部手術室 松下真奈 E-mail: manam@kuhp.kyoto-u.ac.jp] 
Effect of Appropriate Management of the Urine Collection Bag in the Operation Room

\author{
Mana Matsushita $^{11}$, Mio KimUra ${ }^{11}$, Akiko Hashimoto ${ }^{2,3)}$, Junko IgawA ${ }^{2)}$, \\ Hiroe YamanaKa ${ }^{2)}$, Miki NaGaO ${ }^{3)}$, Syunji TAKAKURA ${ }^{3)}$ and Satoshi IchiYama ${ }^{3)}$ \\ ${ }^{1)}$ Surgery Unit, ${ }^{2)}$ Nursing Department, and \\ ${ }^{3)}$ Department of Infection Control and Prevention, Kyoto University Hospital
}

\begin{abstract}
Catheter-associated urinary tract infection (CAUTI) accounts for approximately $40 \%$ of hospital infections, and $80 \%$ of CAUTI cases occur after operation involving urethra catheters and urine collection bags (urine bag). A preliminary investigational study found that urine bags were left on the floor and those bags might be contaminated. In order to implement appropriate handling of urine bags, holders were installed for urine collection bags (holder) and buckets for urine waste fluid (bucket). However, knowledge and motivation about CAUTI prevention among operating room nurses and the utilization rate of those products remained low before this study. The aim of this study was to increase appropriate handling of holders and buckets to prevent CAUTI due to contaminated urine bags. As a multi-disciplinary intervention including educational meetings, posthoc tests, and on-site audit activities, utilization rate of holders rose from $35.9 \%$ to $81.8 \%$ and that of buckets was kept high. Use of a holder was effective to prevent contamination of the drainage port by stability in the urine bag. Giving concise information on the effectiveness of holders and prevention of CAUTI as well as feedback of on-site audit were useful for raising the motivation of operating room nurses to prevent CAUTI by using holders and buckets.
\end{abstract}

Key words : catheter-associated urinary tract infection, operation room, catheter retained in the urinary tract, urine collection bag 